\title{
ROMANTICISM IN WS RENDRA'S SURAT CINTA
}

\section{Takwa}

Faculty of Teacher Training and Education, Sembilanbelas November University of Kolaka, Indonesia takwarachman68@gmail.com

\section{Burhanuddin Arafah}

Faculty of Cultural Sciences, Hasanuddin University of Indonesia

burhan-arafah@unhas.ac.id

\section{Abdul Jumail Syam}

Faculty of Teacher Training and Education, Sembilanbelas November University of Kolaka, Indonesia,Universitas Sembilanbelas November Kolaka ,abduljumail96@gmail.com

\section{Andi Kaharuddin}

Faculty of Education and Teacher Training, Univerisitas Islam Negeri (UIN) Alauddin Makassar of Indonesia andi.kaharuddin@uin-alauddin.ac.id

\section{Kadaruddin}

Faculty of Teacher Training and Education, Sembilanbelas November University of Kolaka, Indonesia s.kadaruddin@yahoo.com

\begin{abstract}
Poetry is a literary work of two different worlds, the ideal world and the factual world. This research describes the ideal world and the factual world, gap/opposition or equivalent. The method is descriptive qualitative. The research results showed an equivalent and opposition in the poetry of Surat Cinta (love letter) by WS Rendra. The equivalent is seen in the aspects of romance leading to: (1) passion, (2) love, (3) remembered and thought in the heart, (4) restless, (5) worried, and (6) sad. Whereas, the opposition is seen in the aspect of expression in the form of: (1) thoughts with feelings, (2) men with women, (3) love with grief, and (4) sweetly with bitterly. The equivalent and opposition in the poetry of Surat Cinta by WS Rendra as a whole build the integrity of meaning in poetry.
\end{abstract}

KeyWords:

Romanticism, Poetry, Equivalent, Opposition

Article Received: 18 October 2020, Revised: 3 November 2020, Accepted: 24 December 2020

\section{INTRODUCTION}

Poetry is a kind of literary works with slightly words but dense of meaning as seen in the structure of poetry in utilizing very limited words, arrays and stanzas (Arafah, B. \& Kaharuddin 2019). In the density and limitations of words used in poetry it contained a very broad meaning. The density of meaning lies in the poetry meaning convention that uses two dimensions of meaning at once, namely meaning dimensions of denotation and connotation (Arafah, B., Thayyib, M., Kaharuddin, \& Sahib, H. 2020). The utilization of both dimensions of meaning can represent two different worlds, namely the ideal world and the factual world on which romanticism theory arises (Arafah, B. \& Hasyim, M 2019).
Romanticism is an understanding developing in literature that operationally works on two things, namely the ideal world and the factual world (Hasjim, M., Arafah, B., Kaharuddin, Verlin, S, \& Genisa, R. A. A. 2020). The ideal world views the ideas, thoughts and ideas stemming from the gaps that occur in life both personally and socially. Everything that occurs in an ideal world is always seen correct as ordinance, law, customary and religious (Arafah, B., \& Kaharuddin, 2019, Purwaningsih, Y. R., Arafah, B., \& Abbas, H. 2020). In contrast, the factual world is not always in line with the ideal world. In this condition, a clash between the world of ideas and the factual world occurs. Poetry is then present to neutralize the condition of the gap 
between the ideal world and the factual world. It gives a description, break down, provides solutions to the existing gaps (Samsuddin, 2016, Hasyim, M., Nursidah, \& Hasjim, M. 2019).

The poetry Surat Cinta (Love Letter) by WS Rendra can not be separated from the gap in question, being able to interpret poetry means be able to free the imagination to interpret every word having meaning power and capture the message represented by the poet. The poetry of Surat Cinta contained meaning of a great love story of the poet with a woman (Dik Narti) ranging from admiring, expressing love and then proposing to marry him. A poetry with strong language style, neat sound, enchanting metaphors and visual imaginary depictions can build the integrity of meaning in WS Rendra's Surat Cinta.

Poetry is a concrete and artistic human thought in emotional and rhythmic language. Therefore, analyzing poetry is sometimes difficult because it is not easy to interpret the nucleus of poetry in chaos of feeling. The elements in poetry are very broad, one of which is known as figurative language. This figurative element is the language used to give attention to anyone as a literary perpetrator. The goal is in addition to making poetry more interesting and varied also provides an overview of the interpretation of imagination. (Pradopo, 2005, Arafah, K., Arafah, A. N. B., \& Arafah, B. 2020).

Poetry is an imaginative statement of feeling, namely the feelings recorded. The feelings and thoughts of poets who are still abstract are made concrete. Poetry is a means of manifesting the events been recorded in poet's mind and feelings. Manifesting the intuition by words is done as efficient as possible. Poetry is a complex work (Hasanuddin, 2002, Andi, K., \& Arafah, B. 2017)

Romanticism is an ideological and literary understanding that affects the whole of literature. However, it does not make the Indonesian literature a uniform phenomenon. The understanding is in itself contradictory. On one hand, romanticism discovers the everyday reality, but on the other hand it tries to find another reality behind without leaving the reality of everyday life. Therefore, it is not surprising that when entering Indonesia, it is vulnerable to division (Faruk, 2012).

Romanticism can also be applied or expressed in art forms, especially music and painting, so that the idea of romanticism as a literary work mostly in the form of poetry begins to be taught in schools and universities as a form of culture. Romantic stories tend to feature things dealing with one's feelings. Exotic, longings in the past are used for the feelings of the audience, beauty and good looks are always told. The authors in romantic era showed great longing and interest in various classic and traditional problems (Hoffman, in Maunder, 2010: 6-7).

Romanticism aspect is divided into two parts, namely the aspect of romance and the aspect of expression. The aspect of romance in poetry is the combination or unity between the real world and the ideal world that the realization is sometimes satisfying even vice versa. The romantic aspect of romance in poetry is the combination or unity between real life and the ideal world. The benchmark of analysis in this discussion is about compassion between the main perpetrator and the perpetrator of the opposite sex, such as love, romance, sadness and other feelings (Kaharuddin, Ahmad, D, Mardiana, Rusni 2020). In the aspect of expression, according to Faruk (1995), romanticism aspects of poetry can be analyzed through the units of expression, such as emotions, uncontrolled desire for love, because romanticism is a set of tools of expression and a set of contents. The unit of expression of romanticism is in the form of opposition between feeling and mind, men and women, hate and longing, love and grief, poor and rich, sweet and bitterness, come and go, soliture and hustle. Based on some theories above, this study aims to describe romanticism in the poetry of Surat Cinta by WS Rendra.

METHOD 
This research includes a literature research with descriptive method. This method attempts to describe the characteristics of the phenomenon investigated (Ismail,. Sunubi, A. H., Halidin, A., \& Amzah., Nanning., Kaharuddin. 2020). The research instrument is the researchers themselves. In this case, the researchers collect, interpret, expose and analyze data. The research data are written data in form of words, arrays, and verses related to romanticism in the poetry of Surat Cinta by WS Rendra as the data source. Data were collected by reading and recording the text of Surat Cinta by WS Rendra in order (1) reading poetry, (2) recording the entire data obtained from the reading, and (3) identifying the details of the problem in accordance with the scope of the research. The collected data were analyzed by using the theory of romanticism which dissects poetry in two ways: (1) poetry is seen as part of the ideal world created by the author and (2) poetry is seen as a factual world that takes place in everyday life. Furthermore, the poetry is seen whether there is a gap /opposition or an equivalent.

\section{RESULT AND DISCUSSION}

Romanticism is a tradition in literature that emphasizes the expression of feelings as the basis of its manifestation (Ephsa, 2015, Arafah, A. N. B., Arafah, A. D. B., \& Arafah, B. 2020). Romantics prefer feeling (emotion, passion), imagination, and intuition. In this relation, WS Rendra's Surat Cinta highlights the aspects of romance as the part that dominates the human mind and the aspect of expression as part of the overflow of feelings. Dichotomically, the romantic aspects in this poetry relate to: (1) lust,
(2) love, (3) think and remember in heart, (4) agitated, (5) worried, and (6) sad. The aspects of expression include: (1) feelings and thoughts, (2) men and women, (3) joy and sorrow, and (4) sweet and bitter. Further discussion in this research is directed at both aspects.

\section{1) Aspects of Romance}

Romance is an ancient problem of mankind. Romance between the opposite sex (man and woman) is always exciting to enjoy or a pattern of entertainment for community (Yulianto, 2019, Arafah, A. N. B., \& Setiyawati, D. 2020). Romance for poets becomes a source of inspiration always brings a new nuance. Romance is inserted in literary works directly or indirectly in which the poets use parables in the form of objects, animals and atmosphere to obtain an unfulgared impression. Specifically in the poetry of Surat Cinta the poet chooses two grouses to express the love of I and Dik Nardi. In relation to this research, the romance is seen from the ideal world and the factual world that can be equivalent or opposition.

Specifically, the aspects of romance in the poetry of Surat Cinta by WS Rendra are manifested in the form of word choices, such as: (1) lust, (2) love, (3) thought and remembered in heart, (4) agitated, (5) worried, and (6) sad. The description of the aspects of romance is discussed below.

1) Lust

Lust is a term in sexuality indicating the physical and mental state or readiness of an individual to have sexual intercourse. The situation can be traced in the poetry Surat Cinta by WS Rendra as in the following data.

\begin{tabular}{l|l}
\hline \multicolumn{2}{c}{ Equivalent in Aspect of Lust } \\
\hline \multicolumn{1}{c|}{ Ideal World } & \multicolumn{1}{c}{ Factual World } \\
\hline $\begin{array}{l}\text { dua ekor belibis } \\
\text { Two grouse) }\end{array}$ & $\begin{array}{l}\text { Penyair dan Dik Narti } \\
\text { (Poet and Dik Narti) }\end{array}$ \\
\hline $\begin{array}{l}\text { aku membimbingmu ke Altar untuk } \\
\text { dikawinkan }\end{array}$ & $\begin{array}{l}\text { Penyair membawa Narti untuk dikawinkan } \\
\text { (The poet took Narti somewhere to be mated) }\end{array}$ \\
\hline
\end{tabular}


(I led you to the altar to be mated).

In the first data, dua ekor belibis (two grouse) personalize the poet and Dik Narti. Such personalization leads to an equivalent between the factual world and the ideal world. The personalization of two grouse forms a relationship equivalent to lovemaking. If it refers to the factual world, the two grouse personalizes the figure of the poet and Dik Narti whose relationship violates the customs or laws that apply in society. However, if we refer to the ideal world then the relationship shows a matter of compassion, love and affection.

In the second data, aku membimbingmu ke Altar dikawinkan (I led you to the altar to be mated) is an equivalent thing. The citation of the poetry illustrates that the poet wishfully takes Narti to the Altar to be mated. In factual world, the word mated refers to relationships in the aspects of lust because it illustrates that the poet wants to take Narti somewhere to be married or to have sexual intercourse. However, if it is connected with the ideal world, then it shows a situation that forms a household in a husband and wife bond.

\section{2) Love}

Love is a verb exoressing an action, existence and experience. The situation can be traced in the poetry Surat Cinta by WS Rendra as in the following data.

\begin{tabular}{l|l}
\hline \multicolumn{2}{c}{ Ekuivalent in Aspect of Love } \\
\hline \multicolumn{1}{c}{ Ideal world } & \multicolumn{1}{c}{ Factual world } \\
\hline Cinta (love, beautiful, like, dear) & Cinta (uncertain circumstances) \\
\hline Kupinang (propose Narti for marriage ) & $\begin{array}{l}\text { Kupinang (a heavy burden felt by the poet } \\
\text { when he wants to marry Narti) }\end{array}$ \\
\hline
\end{tabular}

The first data explains that love shows an expression used by the poet for Narti. Love expressed by the poet contains two equivalent things. When viewed from the factual world love is an uncertain situation, sometimes someone ends their relationship with love and even takes his life. However, in ideal world, love describes a matter of liking, beautiful, dear and enamored between husband and wife, brother and sister, leaders and members.

The second data, kupinang shows a subject of love drawn from the figure of the poet who wants to marry Narti. If it is considered in the ideal world and the factual world then there is an equivalent. The combination of the equivalent can be traced through the poet who wants Narti to get marriage. However, the situation is combined with factual circumstances. The situation that became a heavy burden felt by the poet when he wants Narti to get marriage, because the obstacles that befell the poet come in succession.

3) Thought and Remembered in Heart

Thought and remembered in heart is something already contained in a memory when there is a wish to do something. The situation can be traced in the poetry Surat Cinta by WS Rendra as in the following data.

Ekuivalent in Aspect of Thought Remembered in Heart

\begin{tabular}{l|ll}
\hline \multicolumn{1}{c|}{ Ideal World } & \multicolumn{1}{|c}{ Factual World } \\
\hline $\begin{array}{l}\text { kutulis surat (notes expressing a feeling of } \\
\text { love) }\end{array}$ & $\begin{array}{l}\text { langit menangis (the poet could not } \\
\text { continue writing his letter) }\end{array}$ \\
\hline Anak-anak peri (beautiful wishful thinking, & gaib (horrible, scary and even creepy) \\
\hline
\end{tabular}




\begin{tabular}{l|l}
\hline entertain, happy, full of excitement) & $\begin{array}{l}\text { penyair dari kehidupan sehari-hari (new view } \\
\text { of the poet on unthinkable things) }\end{array}$ \\
$\begin{array}{l}\text { Kehidupan (something hard, complicated, } \\
\text { and sometimes slumped in the abyss of } \\
\text { grief) }\end{array}$
\end{tabular}

The first data, kutulis surat, is an ideal world present in the poet's mind to write a beautiful writing to express a feeling of love that Narti wants to marry him one day. The ideal world and the factual world are equivalent to each other. If it is traced based on the factual world, the expression kutulis surat is his soul expression for Narti. However, these expressions made it impossible for the poet to continue the letter he wrote because langit menangis indicating the poet to stop writing.

The second data, anak-anak peri dunia yang gaib, comes into the poet's wishful thinking as the concept of the ideal world. Anak-anak peri dunia yang gaib is one entity that penetrates everything make it so beautiful, entertaining, fun, and even full of joy. However, this ideal condition forms the equivalent with factual condition that the gaib (supernatural) shows a terrible, frightening and even sinister state. Hence, the ideal world and the factual are equivalent of each other.

The third data, penyair dari kehidupan sehari-hari (the poet in everyday life) contain meaning that gives the poet a new view of unthinkable things. This condition is present in the wishful thinking of the poet as the concept of ideal world. However, this ideal condition is equivalent to factual condition that kehidupan (life) also sometimes describes something hard, complicated, and sometimes so plunged into the abyss.

4) Agitated

Agitated is a state of insecurity, unhappy, restless, and worried. The situation can be traced in the poetry Surat Cinta by WS Rendra as in the following data.

\begin{tabular}{l|l}
\hline \multicolumn{2}{c}{ Ekuivalent in Aspect of Agitated } \\
\hline \multicolumn{1}{c}{ Ideal World } & \multicolumn{1}{c}{ Factual World } \\
\hline hujan (hint of fertility and prosperity) & $\begin{array}{l}\text { hujan (the condition reminiscent of the gray } \\
\text { events have ever occurred }\end{array}$ \\
\hline $\begin{array}{l}\text { angin laut (excitement, and cool when } \\
\text { blowing) }\end{array}$ & angin laut (chaos and hardship) \\
\hline
\end{tabular}

The first data, hujan (raining), is an ideal world that hints at fertility and prosperity, the most exciting time for children to play and have fun. The concept of the ideal world gives new hope. However, a new view as an ideal world concept can be equivalent to factual condition which sometimes does not make the rain as a state that reminds a person of the gray events they have ever experienced, and sometimes the rain results in natural disasters to occur.

The second data, angin laut (sea breeze), is an ideal world describing something exhilarating, soothing when blowing and sometimes the sea breeze is like a relentless sea sculling the boat, holding the steering wheel and keeping the sails stable. The ideal world is equivalent to the factual world. The equivalent of an ideal and factual world makes angin laut depicting chaos and difficulty if we are unable to maintain the stability of the boat and may produce waves that result in loss in the middle of a vast ocean.

5) Worried

Worried is a feeling that shows anxiety, chaos, messy, and so forth. The situation can be traced in the poetry Surat Cinta by WS Rendra as in the following data. 


\begin{tabular}{l|c}
\hline \multicolumn{2}{c}{ Ekuivalent in Aspect of Worried } \\
\hline \multicolumn{1}{c}{ Ideal World } & \multicolumn{1}{c}{ Factual World } \\
\hline $\begin{array}{l}\text { bunyi tambur (melodious, beautiful, and } \\
\text { comfortable to hear) }\end{array}$ & bunyi tambur (no exciting and unenjoyable ) \\
\hline
\end{tabular}

Based on the data above, it can be explained that bunyi tambur as the ideal world of poets describes a melodious, beautiful, and comfortable sound to be heard. These ideal conditions form the equivalent of the factual condition that bunyi tambur as a sound that is not exciting and unejoyable for the poet to write a letter addressed to Narti. This led the poet to stop writing.
6) Sadness

Sadness is an unpleasant situation or even not in accordance with our wishes and expectations. Sadness sometimes creates unpleasant feelings. The situation can be traced in the poetry Surat Cinta by WS Rendra as in the following data.

\begin{tabular}{l|ll}
\hline \multicolumn{3}{c}{ Ekuivalent in Aspect of Sadness } \\
\hline \multicolumn{1}{c|}{ Ideal World } & \multicolumn{1}{c}{ Factual World } \\
\hline menangis (solution) & $\begin{array}{l}\text { Menangis (distress, suffering, sore, grief, } \\
\text { hardship) }\end{array}$ \\
\hline
\end{tabular}

Menangis (crying) in a poetry is an ideal world that exists in the mind of poets. The presence of the word menangis as an ideal world concept describes a solution, because it is with crying the poet gets a solution. By crying the poet can get a response from Narti or the people around him. Crying causes the poet to get affection and other responses, and Narti will give him peace and comfort. Thus crying can describe a positive impact. However, this condition is equivalent to factual conditions. Crying is a symbolic expression reflecting the feelings of distress, suffering, sore, hardship and grief that the poet may feel (Hasyim, M., Arafah, B., \& Kuswarini, P. 2020).

\section{Aspect of Expression}

The aspect of expression is opposition or contradiction between the factual world and the ideal world. This aspect leads to oppositional relationships. The oppositional relationships in the poetry of Surat Cinta by WS Rendra are: (1) feelings and thoughts, (2) men and women, (3) joy and sorrow, and (4) sweet and bitter. The oppositions will be discussed as follows:

1) Feelings and Thoughts

Feelings underlie the manifestations of romance (Efsa (2015: 188). The poetry of Surat Cinta by WS Rendra forms an opposition to one another. This opposition can be seen in the data below.

\begin{tabular}{|c|c|}
\hline \multicolumn{2}{|c|}{ Oposition between Feeling and Thought } \\
\hline Ideal World & Factual World \\
\hline $\begin{array}{l}\text { Kutulis surat } \\
\text { (I write a letter) }\end{array}$ & $\begin{array}{l}\text { hujan gerimis } \\
\text { (drizzling rain) }\end{array}$ \\
\hline $\begin{array}{l}\text { kaki-kaki hujan } \\
\text { (rain feet) }\end{array}$ & $\begin{array}{l}\text { menyentuhkan ujungnya ke bumi } \\
\text { (touch its tip to the earth) }\end{array}$ \\
\hline kata yang bermula dari kehidupan (words & penyair dari kehidupan sehari-hari \\
\hline
\end{tabular}


originated from life)

The oppposition can be seen in Kutulis surat and hujan gerimis. Kutulis surat (I writer a letter) is an imaginary world that the poet builds, envisions and hopes for, namely surat (a letter) with the hope that one day the poet can propose Narti for marriage. The hope is opposed to a factual situation, a situation through which the poet could not get to reach Narti because it is hujan gerimis (drizzling raining).

Opposition between kaki-kaki hujan dan menyentuhkan ujungnya ke bumi is explained that kaki-kaki hujan (rain feet) is an imaginary world that the poet builds and envisions. This condition shows that love is very powerful. However, this imaginary condition is opposed to the factual condition menyentuhkan ujungnya ke bumi (touching its tip to the earth) where it can be said that it is difficult to reach Narti. (poets from everyday life)

Opposition can be seen in penyair dari kehidupan sehari-hari (poets from everyday life) and kata yang bermula dari kehidupan (words originated from life). The word that begins with life is an imaginary world built and imagined by the poet. This condition illustrates that life is formed by a communication between individuals and others. However, this imaginary condition is opposed to the factual condition of the poet from everyday life which can be explained that this situation is real evidence. A poet is a person whose ability is formed as a result of a very long process, the result of learning and experiences having been passed.

2) Man and Woman

The man and woman in the poetry Surat Cinta by WS Rendra form an opposition to each other. The opposition can be seen in the data below.

\begin{tabular}{|c|c|}
\hline \multicolumn{2}{|c|}{ Oposition between Man and Woman } \\
\hline Ideal World & Factual World \\
\hline $\begin{array}{l}\text { Wahai dik Narti aku cinta kepadamu } \\
\text { (Oh Dik Narti, I love you) }\end{array}$ & $\begin{array}{l}\text { Penyair dengan Dik Narti } \\
\text { (The poet and Narti) }\end{array}$ \\
\hline $\begin{array}{l}\text { Wahai dik Narti kupinang kau menjadi istriku } \\
\text { (Oh Dik Narti, Will you marry me?) }\end{array}$ & $\begin{array}{l}\text { Penyair dengan Dik Narti } \\
\text { (The poet and Narti) }\end{array}$ \\
\hline $\begin{array}{l}\text { Wahai dik Narti dengan pakaian pengantin yang } \\
\text { anggun bunga-bunga serta keris keramat aku ingin } \\
\text { membimbingmu ke altar untuk dikawinkan } \\
\text { (O Dik Narti, dressed in elegant bridal clothing, } \\
\text { flowers and a sacred kris, I want to guide you to the } \\
\text { altar to be married) }\end{array}$ & $\begin{array}{l}\text { Penyair dengan Dik Narti } \\
\text { (The poet and Narti) }\end{array}$ \\
\hline $\begin{array}{l}\text { Wahai dik Narti ku ingin kau menjadi ibu anak- } \\
\text { anakku } \\
\text { (O Dik Narti, I want you to be the mother of my } \\
\text { children) }\end{array}$ & $\begin{array}{l}\text { Penyair dengan Dik Narti } \\
\text { (The poet and Narti) }\end{array}$ \\
\hline $\begin{array}{l}\text { Engkau adalah putri duyung tawananku putri duyung } \\
\text { dengan suara merdu lembut bagai angin laut } \\
\text { mendesahlah bagiku } \\
\text { (You are the mermaid my captive mermaid with a soft } \\
\text { sweet voice like the sea breeze, sigh for me) }\end{array}$ & $\begin{array}{l}\text { Penyair dengan Dik Narti } \\
\text { (The poet and Narti) }\end{array}$ \\
\hline Wahai putri duyung aku menjaringmu aku & Penyair dengan Dik Narti \\
\hline
\end{tabular}




\begin{tabular}{|c|c|}
\hline $\begin{array}{l}\text { melamarmu } \\
\text { (O mermaid, O mermaid, I net you I propose you for } \\
\text { marriage) }\end{array}$ & (The poet and Narti) \\
\hline $\begin{array}{l}\text { Engkau adalah putri duyung tergolek lemas } \\
\text { mengejab-ngejabkan matanya yang indah dalam } \\
\text { jaringku } \\
\text { (You are a mermaid, lying limp, fluttering her } \\
\text { beautiful eyes in my net) }\end{array}$ & $\begin{array}{l}\text { Penyair dengan Dik Narti } \\
\text { (The poet and Narti) }\end{array}$ \\
\hline
\end{tabular}

This opposition is shown by Narti and the poet. The description of opposition is based on data 1, 2, 3 and 4. Nati is in imaginary a female figure that the poet dreams. However, this imaginary condition is opposed to a factual condition where the poet is a male figure who idolizes a certain woman to be the mother of his children.

The opposition is shown by putri duyung (the mermaid) and $a k u$ (I). The description of the Opposition is based on the data 4, 5 and 6. Putri duyung (the mermaid) is in imaginary a woman poets dreams and depicts his admiration for his lover as a mermaid. However, this imaginary condition is opposed to the factual situation where the poet is a male figure who has a strong spirit and does not easily give up to get marriage with Narti.

3) Joy and Grief

Joy and sorrow in the poetry Surat Cinta by WS Rendra form an opposition to one another. The opposition can be seen in the data below.

\begin{tabular}{l|l}
\hline \multicolumn{1}{c}{ The Opposition between Joy and Grief } \\
\hline \multicolumn{1}{c}{ Ideal World } & \multicolumn{1}{c}{ Factual World } \\
\hline $\begin{array}{l}\text { bunyi tambur mainan anak-anak peri dunia } \\
\text { (the tambour sound of the toys of fairy's }\end{array}$ & $\begin{array}{l}\text { angin mendesah mengeluh dan mendesah } \\
\text { (the wind sighing and sighing) }\end{array}$ \\
$\begin{array}{l}\text { khildren the unseen fairy world) } \\
\text { (I write a letter) }\end{array}$ & $\begin{array}{l}\text { langit menangis } \\
\text { (Sky crying) }\end{array}$ \\
$\begin{array}{l}\text { cinta yang tegas bagai logam berat } \\
\text { gemerlapan } \\
\text { (firm love as sparkling-heavy metal) }\end{array}$ & \begin{tabular}{l} 
(never postponed) \\
\hline
\end{tabular}
\end{tabular}

The opposition to bunyi tambur mainan anak-anak peri dunia yang gaib (the tambour sound of the toys of fairy's children the unseen fairy world) and angin mendesah mengelu dan mendesah (the wind sighing and sighing) is in bunyi tambur mainan anak-anak peri dunia yang gaib as the imaginary world, that is Narti does not yet finish telling the story of the children's toys, a condition exhilarating to hear. However, the imaginary condition above is oposed to the factual condition of angin mendesah mengelu dan mendesah (the wind sighing and sighing), a situation that allows a condition of sighing. This makes it impossible for the poet to hear the story about the the tambour sound of the toys of fairy's children, because the wind had sighed.

Opposition kutulis surat (I write a letter) and langit menangis (the sky crying). Kutulis surat is a condition allow the poet to survive, undergoing the love story every human being wants, turn it into energy to survive in any condition. However, this condition is discarded 
with the factual condition of langit menangis (the sky crying) which seems to be stronger than just a hope, because it is not just a hope but also a struggle, an unavoided reality.

The opposition of cinta yang tegas bagai logam berat gemerlapan (love as firm as sparkling-heavy metal) and tak'kan kunjung diundurkan (never postponed) suggests two opposing things, namely the imaginary world and the factual world. Cinta yang tegas bagai logam berat gemerlapan (firm love as a glittering heavy metal) is the imaginary world the poet built, dreamed of and expected, that is great love and how it feels that brings happiness to love Narti. The hope is opposed to the factual condition tak'kan kunjung diundurkan (never postponed), a situation that does not allow the poet to reach Narti because it has been postponed. The situation where he ends everything.

3) Sweet and bitter

Sweet and bitter in the poetry Surat Cinta by WS Rendra forms an opposition to one another. The opposition can be seen in the data below.

\begin{tabular}{l|l}
\hline \multicolumn{2}{c}{ Oposition between Sweet and Bitter } \\
\hline \multicolumn{1}{c}{ Ideal World } & \multicolumn{1}{c}{ Factual World } \\
\hline $\begin{array}{l}\text { Aku melamarmu } \\
\text { (I propose you for a marriage) }\end{array}$ & $\begin{array}{l}\text { tiada lebih buruk dan tiada lebih baik } \\
\text { (nothing worse and nothing better) }\end{array}$ \\
\hline $\begin{array}{l}\text { kantong rejeki dan restu wingit } \\
\text { (bag of fortune and blessings) }\end{array}$ & $\begin{array}{l}\text { tumpahlah gerimis } \\
\text { (the drizzle spilling) }\end{array}$ \\
\hline
\end{tabular}

The opposition aku melamarmu (I propose you for a marriage) and tiada lebih buruk dan tiada lebih baik (nothing worse and nothing better) shows two opposing things, namely the imaginary world and the factual world. $A k u$ melamarmu (I propose you for a marriage) states the condition of enthusiasm, optimism, and hard work built by the poet. However, this condition is opposed to a factual condition tiada lebih buruk dan tiada lebih baik (nothing worse and nothing better), where the situation that the poet had built for Narti is not easy as expected.

The opposition kantong rejeki dan restu wingit (bag of fortune and blessings) and tumpahlah gerimis (the drizzle spilling). Kantong rejeki dan restu wingit (bag of fortune and blessings) leads to the efforts of the poet to defend and protect love in a sturdy container so that one day the drizzle does not wet the love, a solid condition in the image of a poet to save and care for every trace of love. This situation is opposed to tumpahlah gerimis (the drizzle spilling), a condition the poet must undergo if he keeps fortune and blessings. This situation becomes a factual condition experienced by the poet in keeping every trace of love.

\section{Conclusion}

Romanticism in the poetry of Surat Cinta by WS Rendra can be distinguished into two aspects, namely (1) aspects of romance and (2) aspects of expression. The aspect of romance is the ideal world and the factual world in line that produce the equivalent. The fusion or unity between the ideal world and the factual world can be seen in: (1) lust, (2) loving, (3) thought and remembered in heart, (4) inconvenient, (5) worried, and (6) sad. Meanwhile, the aspect of expression is an ideal world that is not in line with the factual world resulting in opposition. The opposition leads to: (1) thoughts and feelings, (2) men and women, (3) joy and grief, and (4) sweet and better. The equivalent and opposition between the ideal world and the factual world in the poetry Surat Cinta by WS Rendra as a whole build the integrity of meaning in the poetry. 


\section{References}

[1] Andi, K., \& Arafah, B. (2017). Using needs analysis to develop English teaching materials in initial speaking skills for Indonesian college students of English. The Turkish Online Journal of Design, Art and Communication (TOJDAC), Special Edition, 419-436.

[2] Arafah, B., \& Kaharuddin, (2019). The Representation of Complaints in English and Indonesian Discourses. Opción, 35, 501-517.

[3] Arafah, B. \& Kaharuddin (2019). The Idol: A Model for Incorporating Literature in ELT. KnE Social Sciences, 43-59.

[4] Arafah, B. \& Hasyim, M. (2019). Linguistic functions of emoji in social media communication. Opcion. Vol. 35 (24), 558574.

[5] Arafah, K., Arafah, A. N. B., \& Arafah, B. (2020). Self-Concept and Self-Efficacy's Role in Achievement Motivation and Physics Learning Outcomes. Opción, 36, (27), 1607-1623

[6] Arafah, B., Thayyib, M., Kaharuddin, \& Sahib, H. (2020). An anthropological linguistic study on Maccera' Bulung ritual, Opción, 36, (27), 1592-1606

[7] Arafah, A. N. B., \& Setiyawati, D. (2020). Volunteerism in Sub-District Social Welfare Worker in Dosaraso Halfway House. International Journal of Psychosocial Rehabilitation, 24(Special Issue 1), 357362. doi: $10.37200 /$ ijpr/v24sp1/pr201165

[8] Arafah, A. N. B., Arafah, A. D. B., \& Arafah, B. (2020). Gene Therapy for the Treatment Of X-Linked Retinitis Pigmentosa: A Review. European Journal of Molecular \& Clinical Medicine, 7(8), 15241532.

[9] Efsa, Nita Widiati. 2015. Manifestasi Ideologi Romantik dalam Puisi-Puisi Acep Zamzam Noor. Litera. Vol. 14, No. 1 (April 2015).
[10] Faruk. 1995. Perlawanan Tak Kunjung Usai: Sastra, Politik, dan Dekonstruksi. Yogyakarta: Pustaka Belajar.2012. Novel Indonesia, Kolonialisme dan Ideologi Emansipatoris. Yogyakarta: Ombak.

[11] Hasanuddin. 2002. Membaca dan Menilai Sajak, Pengantar, Pengkajian, dan Interprestasi. Bandung: Angkasa Bandung.

[12] Hasjim, M., Arafah, B., Kaharuddin, Verlin,S, \& Genisa, R. A. A. (2020). Principles Behind Semantic Relation between Common Abbreviations and their Expansions on Instagram. International Journal of Criminology and Sociology, 9, 2270-2276.

[13] Hasyim, M., Nursidah, \& Hasjim, M. (2019). Online advertising: how the consumer goods speaks to women. Opción, 35(89), 826-845.

[14] Hasyim, M., Arafah, B., \& Kuswarini, P. (2020, October). The new Toraja destination: adding value 'Toraja coffee' of the sustainable tourism development. In IOP Conference Series: Earth and Environmental Science (Vol. 575, No. 1, p. 012072). IOP Publishing.

[15] Ismail,. Sunubi, A. H., Halidin, A., \& Amzah., Nanning., Kaharuddin. (2020). Paraphrasing Technique to Develop Skill for English Writing Among Indonesian College Students of English. Systematic Reviews in Pharmacy, 11(11), 291-297.

[16] Kaharuddin, Ahmad, D, Mardiana, Rusni (2020) Contributions of Technology, Culture, And Attitude To English Learning Motivation During Covid -19 Outbreaks. Systematic Reviews in Pharmacy, 11 (11), 76-84. doi:10.31838/srp.2020.11.13

[17] Maunder, Andrew. 2010. Encyclopedia of Literary Romanticism. New York: An Imprint of Infobase Publishing.

[18] Moleong, Lexy. 1994. Metodologi Penelitian Kualitatif. Bandung: PT Remaja Rosdakarya. 
[19] Pradopo, Rachmat Djoko. 2005. Beberapa Teori Sastra, Metode, Kritik dan Penerapannya. Yogyakarta: Pustaka Belajar. [20] Purwaningsih, Y. R., Arafah, B., \& Abbas, H. (2020). An ambition of infidelity "Emma Bovary" as wife: Sexuality problems. Medicina Clínica Práctica, 3, 100-108.

[21] Rendra, WS. 1990. Empat Kumpulan Sajak Rendra. Jakarta: Dunia Pustaka Jaya.

[22] Samsuddin. 2015. Penerapan Teori Intertekstual pada Puisi Indonesia. Yogyakarta: Deepublish.2016. Romantisme Pada Puisi-Puisi Indonesia: www.Blogger.com. Accessed on Tuesdauy 29 November 2016.

[23] Sehandi, Yohanes. 2014. Mengenal 25 Teori Sastra. Yogyakarta: Penerbit Ombak.
[24] Sugiyono. 2013. Metode Penelitian Kuantitatif, Kualitatif, dan R\&D. Bandung: Alfabeta.

[25] Tarigan, H.G. 2008. Menulis Sebagai Salah Satu Keterampilan Berbahasa. Bandung: Angkasa Bandung.

[26] Wallek, Rane, dan Austin Warren. 1993. Teori Kesusastraan. Jakarta: PT Gramedia Pustaka Utama.

[27] Wiyatmi. 2006. Pengantar Kajian Sastra. Yogyakarta: Pustaka Belajar.

[28] Yulianto, Agus. 2019. Unsur Romantis sebagai Pembentuk Estetika dalam Novel Kau, Aku dan Sepucuk Angpau Merah Karya Tere Liye. Tuah Talino. Vol. XIII, No. 1 (Juli 2019). 